\title{
NARASI GERBANG RUMAH PERANAKAN DI PECINAN, LASEM, JAWA TENGAH: PENDEKATAN FENOMENOLOGI
}

\author{
Tessa Eka Darmayanti $\left.{ }^{1,2 *}\right)$, Azizi Bahauddin ${ }^{2}$ \\ *) Corresponding author email : tessaeka82@gmail.com \\ 1)Program Desain Interior, Fakultas Seni Rupa \& Desain, Universitas Kristen Maranatha, Bandung, Indonesia \\ 2) School of Housing, Building \& Planning, Universiti Sains Malaysia, Penang, Malaysia
}

\author{
Article info \\ MODUL vol 20 no 2, issues period 2020 \\ Doi : : 10.14710/mdl.20.2.2020.126-133 \\ Received : 3 September 2020 \\ Revised : 14 Oktober 2020 \\ Accepted : 6 November 2020
}

\begin{abstract}
The gate is an important component of Peranakan houses in Lasem. They are included in the cultural heritage of Indonesia, and most of them are more than a hundred years old, but still stand firm and lined up neatly adorning the Pecinan area. The purpose of this paper is to provide a different perspective on the existence of the Peranakan houses' gates that interpreted through the author's experiences during the fieldwork. The gate embodiment gives a different atmosphere and experience which is not found elsewhere because they are unique and irreplaceable. Unfortunately, preserving these gates become a serious challenge in the modern era. The finding comes from the phenomenon which found after the field research and analyzed using the phenomenology approach of Merleau Ponty, Juhani Pallasmaa, and Steven Holl. Phenomenology allows people to express their existence through architecture and let its value appear to people as they experience it. The result showed that experiences would give the people have an attachment to the place unconsciously.
\end{abstract}

Keywords: gate; phenomenology; narrative; Peranakan houses; Lasem

\section{PENDAHULUAN}

Keberadaan komunitas Tionghoa di Lasem telah menyebabkan akulturasi budaya, dan salah satunya adalah rumah-rumah Peranakan. Kawasan Pecinan di Lasem dipilih sebagai studi kasus karena masih memiliki komponen yang lengkap sampai saat ini. Masih ada kelenteng sebagai tempat ibadat, pasar dan

Tessa Eka Darmayanti, Azizi Bahauddin perumahan. Perumahan juga masih dengan keadaan karakter asli rumah Peranakan tipe bungalow, yang pada umumnya berada di dalam sebuah kompleks dengan komponen lainnya. kompleks dikelilingi tembok tinggi yang terdiri dari pintu gerbang utama, di dalamnya ada taman di depan, serambi depan dengan bangunan utama, satu atau dua bangunan di sebelah sisi kanan dan kiri, courtyard dan bangunan lain di area belakang rumah. Sebagian besar rumah Peranakan di Pecinan, di kotakota lain sudah terbuka, tidak lagi memiliki tembok tinggi dan juga gerbang. Kenapa harus membahas gerbang? karena bagian terpenting dari rumah Peranakan di Pecinan, Lasem yang menjadi wajah dan identitas utama rumah tersebut. Dari sudut pandang penulis berdasarkan survey dan observasi, keadaan rumah-rumah Peranakan di Lasem sudah dalam tahap kritis. Banyak rumah yang rusak karena tidak dirawat oleh pemilik, penghuni atau pewarisnya dan beberapa bahkan dengan terpaksa atau sengaja dihancurkan untuk tujuan tertentu (gambar 1). Selain itu, ada fenomena alih fungsi yaitu perubahan fungsi rumah-rumah Peranakan, namun dalam perubahannya kurang atau tidak mempertimbangkan nilai budaya dan sejarahnya, sehingga secara fisik terlihat menarik, "berwarna" tetapi telah kehilangan jiwanya (Darmayanti dan Bahauddin, 2020: 266). Dengan demikian, harus ada upaya untuk segera mendokumentasikan objek warisan budaya ini sebagai langkah antisipasi dari kehilangan identitas. Melalui artikel ini, penulis berupaya untuk mengeksplorasi persepsi tentang gerbang-gerbang rumah Peranakan di kawasan Pecinan, Lasem.

Gerbang tidak hanya berfungsi sebagai penghalang antara ruang luar dan ruang dalam di dalam kompleks rumah yang bernilai nyata (tangible), tetapi juga mengandung nilai tidak nyata (intangible). Keberadaan gerbang-gerbang tersebut dapat menawarkan berbagai pengalaman kepada mereka yang mengalaminya dan setiap individu akan memiliki pengalaman dengan perspektif yang berbeda, oleh 
karena itu dapat memberikan arti tersendiri terhadap gerbang.

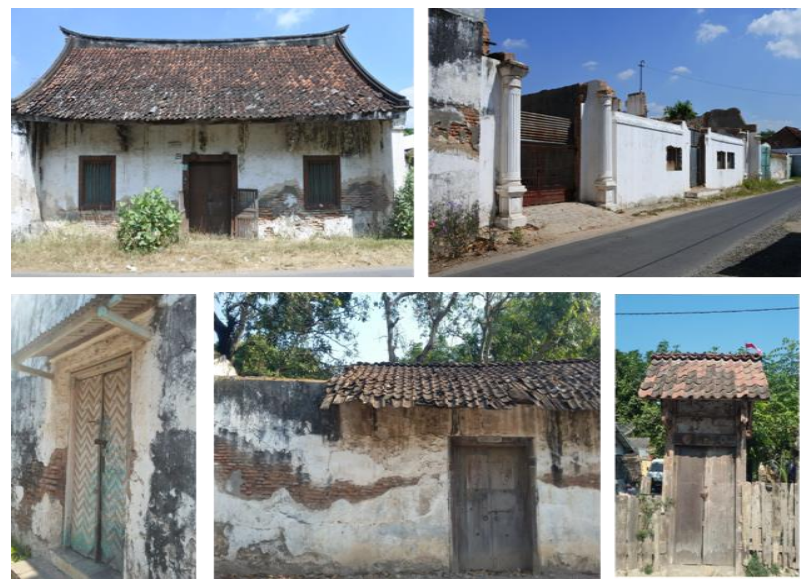

Gambar 1. Berbagai Kerusakan Gerbang dan Rumah Peranakan Tionghoa di Lasem, Jawa tengah (Sumber : Dokumentasi Penulis, 2017-2019)

Lasem dan bangunan heritage di dalamnya telah menarik banyak peneliti sejak lama, seperti James Rush (1990) yang memaparkan tentang kejayaan Lasem dimasa perdagangan opium atau candu sekitar tahun 1860 sampai 1910. Kemudian, bahasan akulturasi budaya pada rumah-rumah Peranakan Lasem di paparkan Suroyo et al (1994). Sedangkan Peter Nas (2002) menguraikan Pecinan Lasem dan rumah Peranakannya lebih spesifik yang dilihat dari aspek kosmologi. Kajian yang mengarah pada tipe dan jenis rumah Peranakan Lasem baru dapat dilihat di dalam penelitian Pratiwo pada tahun 1990 dan di terangkan kembali pada tahun 2010 melalui buku berjudul Arsitektur Tradisional Tionghoa dan Perkembangan Kota. Penelitian tentang rumah Peranakan dan pengaruh budayanya, kembali dapat dilihat melalui Munawar Aziz (2014) dan Handinoto (2015). Walaupun demikian, belum ada yang memberikan gambaran rumah Peranakan Lasem, terutama tentang gerbang yang melibatkan pengalaman manusia. Berdasarkan hal tersebut, artikel ini bertujuan untuk memberikan pandangan yang berbeda tentang keberadaan gerbanggerbang yang ditafsirkan melalui pengalaman penulis yang terjadi selama di lapangan. Melalui pengalaman pribadi, secara tidak disadari akan menghasilkan sense of place. Secara umum, sense of place menggambarkan hubungan seseorang dengan suatu tempat, diekspresikan dalam berbagai reaksi, seperti emosi, narasi, imajinasi dan pengalaman pribadi (Basso, 1996). Pernyataan tersebut diperkuat oleh Russ et al (2015) bahwa sense of place mempengaruhi dan menentukan bagaimana seseorang melihat, menafsirkan, serta berinteraksi dengan apa yang ada di sekitarnya. Jika keterkaitan (attachment) seseorang dengan tempat terbentuk dengan baik, maka dapat membantu seseorang itu menghargai aspek sejarah dan budaya di tempat tersebut.

Agar objektif penelitian dan penjelasan di atas memperoleh kejelasan analisis dan kesesuaian dengan objek penelitian, maka, wawancara telah dilakukan kepada beberapa masyarakat lokal, pakar budaya Lasem, begitu juga kajian literatur telah dilakukan. Berdasarkan uraian tersebut, maka pertanyaan penelitian dirumuskan yaitu apa saja komponen sejarah maupun budaya di gerbang rumah Peranakan Lasem yang memberikan pengaruh pada pengalaman penulis sehingga menciptakan sense of attachment dengan gerbanggerbang rumah Peranakan di Pecinan, Lasem?

Pengalaman penulis yang berhubungan dengan keberadaan gerbang rumah-rumah Peranakan telah dialami selama beberapa kunjungan ke tiga kawasan Pecinan di Lasem yaitu Soditan, Karangturi dan Babagan yang dimulai dari bulan Februari dan berlanjut pada bulan September 2017, November 2017, September 2018 dan Desember 2019. Di dalam artikel ini, penulis ingin menyajikan beberapa pengalaman tersebut yang didukung dengan pengalaman wisatawan yang bertemu pada saat kunjungan. Berbagai pengalaman disajikan melalui pendekatan fenomenologi. Fenomenologi adalah filosofi atau cara menyelidiki suatu kawasan atau objek yang memungkinkan kita untuk "melihat dan mengumpulkan dunia sendiri," setiap "dunia" yang terdapat pada objek penelitian tersebut adalah fenomena, dalam hal ini adalah gerbanggerbang rumah Peranakan di Pecinan, Lasem. Diskusi di dalam fenomenologi membutuhkan persepsi karena melibatkan emosi terhadap objek dan melalui perspektif fenomenologis berbagai kemungkinan yang menjembatani hubungan manusia dengan "dunianya" dapat disajikan. Fenomenologi juga melibatkan kesadaran dan pengalaman peristiwa yang terjadi sehingga menghasilkan pengalamannya sendiri. Merujuk kepada Kusworo (2009), fenomenologi mencerminkan pengalaman langsung manusia, sejauh pengalaman itu dilakukan secara intensif atau berulang-ulang terkait dengan suatu objek. Pakar fenomenologi yang akan disajikan di dalam artikel ini adalah Merleau Ponty (1908-1961), Juhani Pallasmaa (1936-) dan Steven Holl (1947-). Alasan dalam memilih pakar dan teorinya pada artikel ini karena ketiganya memiliki cara pandang yang serupa mengenai pengalaman, persepsi dan arsitektur. Ponty mendefinisikan fenomenologi sebagai studi tentang esesnsi persepsi dan juga memberikan deskripsi langsung tentang pengalaman manusia (Toadvine, 2016). Definisi yang lebih spesifik dari Pallasmaa yang terinspirasi dengan Ponty memiliki definisi aspek fenomenologis dari persepsi kinestetik dan multi sensor tubuh manusia yang dapat membantu pengalaman manusia di dalam lingkungan arsitektural (Pallasmaa, 
2005). Sedangkan Holl seorang arsitek sangat mengagumi berbagai tulisan dari Ponty dan Pallasmaa berpendapat bahwa pendekatan fenomenologis bertujuan untuk melampaui pengalaman manusia di dalam lingkungan arsitektural (MacLeod, 2019). Pendekatan fenomenologi ini pada umumnya disampaikan melalui narasi atau penuturan cerita mengenai sebuah objek dan melalui artikel ini pembaca akan disuguhkan narasi umum tentang gerbang-gerbang rumah Peranakan di Lasem.

\section{TINJAUAN LITERATUR LASEM DAN PECINAN}

Pertanyaan yang sering diutarakan dalam isu sense of place yaitu tempat seperti apa ini?, apa arti tempat ini bagi anda?, dan apa yang diberikan tempat ini kepada anda, serta apa yang anda lakukan untuk tempat ini?. Pertanyaan-pertanyaan tersebut "menyatakan" bahwa pentingnya pengetahuan mengenai latar belakang atau sejarah suatu tempat. Oleh karena itu, tinjauan mengenai Lasem dan Pecinan sangat diperlukan supaya lebih memahami value apa yang terkandung di dalamnya dan apa yang bisa dilakukan untuk memeliharanya.

Sekitar tahun 1303, Laksamana Cheng Ho dari era Dinasti Ming melakukan ekspedisi ke Indonesia. Di Pulau Jawa, ia menemukan banyak komunitas Tionghoa di Lasem yang kemudian dikenal sebagai tempat imigran Tionghoa terbesar di Jawa yang terjadi pada 14 hingga 15 abad. Hal tersebut yang menyebabkan pengaruh kuat budaya Tionghoa ke Jawa sebagai budaya lokal (Darmayanti, 2017). Pada abad ke-16, Lasem adalah salah satu kota penting juga pelabuhan yang aktif di bawah Kerajaan Majapahit dan selama masa kolonial Belanda (1860), Lasem pernah menjadi daerah penting untuk perdagangan opium di Indonesia dan bahkan di Asia (Suroyo, et.al, 1994). Walaupun, latar belakang Lasem ternyata sangat menarik, namun tidak banyak orang yang tahu, tetapi dalam beberapa tahun terakhir, setidaknya di dalam negeri, keberadaan Lasem kemudian diangkat kembali melalui publikasi televisi, media sosial, dan penelitian akademis. Lasem memang tidak terlihat sebagai tujuan utama wisata di pulau Jawa, tetapi kekayaan sejarah dan warisan budayanya yang unik membawa Lasem kembali ke permukaan. Lasem terletak di Jawa Tengah, sekitar 30 menit dari Kabupaten Rembang (gambar 2) yang dapat dicapai melalui perjalanan darat. Jika perjalanan ditempuh dari Jakarta atau Bandung akan memakan waktu delapan jam dengan kereta api sampai Semarang dan dilanjutkan selama tiga hingga empat jam dengan bis. Setelah total sekitar 12 jam perjalanan, Lasem akan menyambut mata kita dengan bangunan warisan bergaya Tionghoa dan kolonial Belanda. Lasem bukan destinasi wisata yang menghadirkan kemewahan karena suasana di kota ini sebenarnya menawarkan "perjalanan ke masa lalu."
Kota ini akan memberikan pengalaman berwisata dalam kesederhanaan namun dipenuhi dengan kekayaan cerita sejarah dan budayanya.

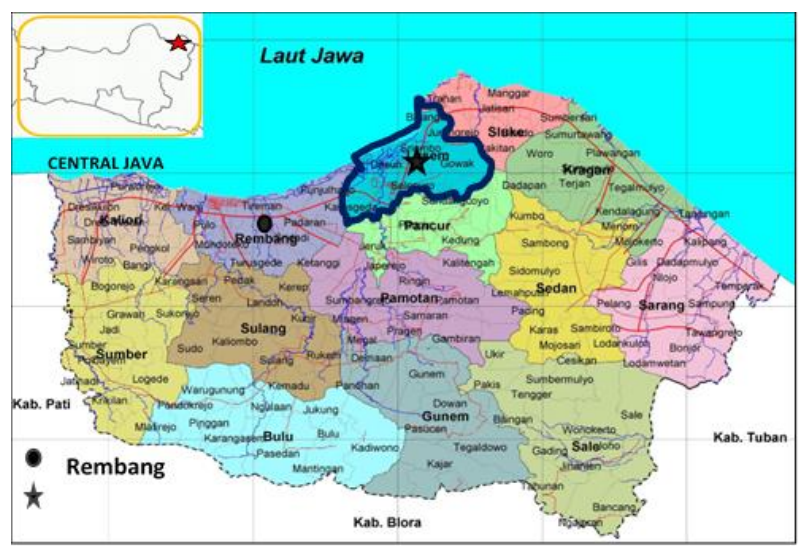

Gambar 2. Lokasi Rembang dan Kecamatan Lasem, Jawa tengah (Sumber: Darmayanti, 2017)

Indonesia memiliki beragam etnis. Di Lasem, etnis Tionghoa, Arab, dan Jawa, bahkan pengaruh kolonial Belanda bergabung menjadi satu. Namun, sangat sulit menemukan perselisihan di Lasem, toleransi berkembang dengan baik turun temurun karena sudah dipupuk dengan baik oleh para leluhur. Salah satu hasil toleransi adalah keberadaan rumah-rumah Peranakan. Rumah-rumah ini tidak hanya dibangun karena keberadaan budaya Tionghoa, juga karena tangan dan hati yang terbuka dari etnis Jawa sebagai komunitas lokal.

Pada umumnya, Pecinan terbentuk berdasarkan pada dua faktor yaitu faktor sosial dan politik. Faktorfaktor sosial terbentuk karena kebutuhan orang-orang Tionghoa dalam melakukan berbagai kegiatan seharihari maupun kegiatan budaya-tradisi dengan keluarga dan komunitas mereka (Handinoto, 2015). Di dalam penelitian Darmayanti \& Bahauddin tahun 2020 dengan judul Understanding Vernacularity through Spatial Experience in the Peranakan House Kidang Mas, Chinatown, Lasem, Indonesia, diketahui bahwa kata Pecinan berasal dari bahasa Jawa yang berarti daerah bagi orang Tionghoa. Menurut Slamet Widjaja (1988), pembangunan Pecinan yang dimulai pada tahun 1351 sampai dengan tahun 1942 difungsikan sebagai pusat kegiatan ekonomi dan perdagangan dan umumnya dengan perumahan, pasar dan pertokoan. Menurut Danang Swastika, penduduk local yang juga ahli sejarah Lasem, menyatakan ada tiga kawasan Pecinan di Lasem termasuk kategori kuno, yakni Soditan, kawasan permukiman pertama yang terletak di dekat pelabuhan Lasem. Daerah tersebut kemudian berkembang ke arah barat sekitar tahun 1750-an yang disebut Karangturi dengan pendatang terbanyak berasal dari Jakarta karena 
pembantaian orang Tionghoa di Jakarta pada waktu itu. Kemudian kawasan Babagan, pemukiman yang berkembang sekitar tahun 1800 dengan sebagian besar orang Tionghoa yang melarikan diri dari kerusuhan di Ngawi (Darmayanti \& Bahauddin, 2020).

Pecinan, selain sebagai pusat ekonomi yang diperlihatkan melalui aktivitas perdagangan. Di sisi lain ada faktor politik berasal dari era kolonial Belanda yang dikenal dengan sebutan wijkenstelsel sekitar abad ke-18 yang berlaku di semua kota besar di Hindia Belanda (Indonesia). Merujuk kepada P.H Fromberg (1911), bahwa wijkenstelsel dibuat dengan tujuan untuk melakukan pengawasan terhadap orang-orang Tionghoa pada masa itu dan jika hendak melakukan perjalanan harus menggunakan "pas jalan" yang diurus oleh seorang wijkmeester atau petugas pengawas. Fromberg adalah seorang Belanda yang berhasil menilai secara adil tentang situasi orang Tionghoa di Hindia Belanda (Indonesia) saat itu dan ia sangat bersimpati kepada orang Peranakan, terutama bagi mereka yang menerima pendidikan Belanda (Suryadinata, 1997).

Berdasarkan berbagai kegiatan masyarakat Tionghoa, umumnya kawasan Pecinan terdiri dari kawasan perumahan, pasar, dan klenteng (gambar 3). Menurut sejarawan Lasem yaitu Slamet Wijaya, kawasan Pecinan di Lasem telah mengalami perkembangan signifikan yang dimulai dari tahun 1351 sampai tahun 1942 kebanyakan dikarenakan adanya penambahan kepala keluarga. Berdasarkan sejarah terbentuknya, kawasan Pecinan di Lasem terbagi menjadi tiga yaitu Desa Soditan, Karangturi dan Babagan. Berdasarkan wawancara dengan Danang Swastika dan Gandor Sugiharto pada September 2017 di Lasem mengatakan bahwa Soditan adalah area Pecinan yang pertama di Lasem. Daerah tersebut adalah muara sungai dan paling dekat dengan pelabuhan. Gandor (2017) menyatakan bahwa mungkin Soditan telah terbentuk pada tahun 1470. Ini berdasarkan pada fakta dari peta yang dibuat pada tahun 1477, Klenteng tertua di Lasem yaitu $\mathrm{Cu}$ An Kiong sudah tergambar disana. Kemudian, Desa Karangturi didirikan sekitar tahun 1740-an, terbentuk dari migrasi besar-besaran orang Tionghoa dari Jakarta yang melarikan diri dari peristiwa pembantaian orang Tionghoa di Jakarta. Selanjutnya, kawasan Pecinan meluas ke arah barat yaitu Babagan atau Palagan yang terbentuk sekitar tahun 1800-an.

\section{PEMBAHASAN}

\section{Persepsi Gerbang Rumah Peranakan}

Sejarah dan budaya selalu menjadi daya tarik penulis; karena itu, lebih mudah bagi penulis untuk mengagumi peninggalan bersejarah. Melalui kekaguman ini, kesadaran penulis secara otomatis memberi penilaian pada artefak bersejarah dengan bantuan panca indera dan perasaan yang berakhir dengan persepsi tertentu. Penulis memiliki persepsi sendiri tentang gerbang rumah Peranakan di tiga daerah Pecinan, Lasem.
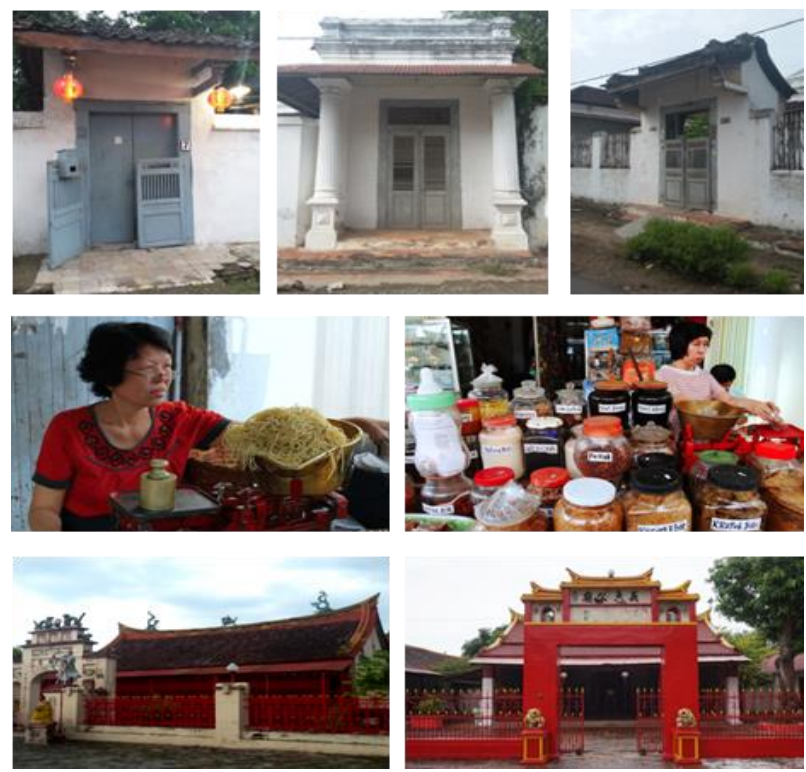

Gambar 3. Komponen Umum Kawasan Pecinan:

Perumahan, Pasar dan Klenteng

(Sumber : Darmayanti, 2017)

Persepsi pada gerbang-gerbang ini berkembang setelah melakukan beberapa kali kunjungan ke area yang sama dan diikuti oleh berbagai pengalaman dan perasaan untuk mendapatkan gambaran yang lebih nyata sehingga pesan-pesan yang terdapat di dalam artefak dapat disampaikan dengan mudah. Pernyataan tersebut sejalan dengan pernyataan Marleau Ponty (2012); "Manusia membutuhkan lebih banyak pengalaman untuk mengembangkan persepsi melalui pengalaman mereka dan melalui kesadaran mereka." Proses terbentuknya persepsi dapat dipengaruhi oleh faktor pribadi seperti usia, pengalaman, proses belajar dan kepribadian. Selain itu, dapat juga berasal dari faktor struktural (eksternal) yang berasal dari luar individu, seperti lingkungan sekitarnya, kondisi sosial dan nilai-nilai yang berlaku di dalam masyarakat (Rahmat, 1985). Berbagai macam persepsi yang dipengaruhi oleh ingatan dan imajinasi kemudian terbentuk setelah berulang-kali melewati gerbang rumah Peranakan di Pecinan, Lasem. Berada di Lasem, seperti berada di "masa lalu," deretan gerbang rumah yang terbuat dari kayu dengan dominasi cokelat yang telah pudar dan hijau dengan dinding putih kusam dengan cat terkelupas memperlihatkan batu bata merah memang memperkuat suasana masa lalu atau tempo dulu. Mereka telah berdiri selama lebih dari 200-an tahun, memang tidak dipelihara dengan baik, namun mereka masih bertahan. Suasana Pecinan di Lasem cenderung sepi, justru itu yang membuatnya lebih 
menarik. Pallasmaa (1994) pernah berkata “...imajinasi akan menempatkan kita pada dunia yang berbeda dengan bantuan aktifasi seluruh panca indera (the senses) yang dimiliki... mata melihat bangunan tua, kulit merasakan sunyi dan hidung dapat membedakan aroma tempo dulu..."

Jika dilihat dari sudut pandang yang berbeda, sebetulnya gerbang rumah Peranakan dapat dilihat sebagai peserta parade budaya dengan menggunakan kostum masing-masing yang membawa karakteristik mereka sendiri. Karakteristik yang diperlihatkan atau bersifat nyata dapat ditinjau dari berbagai elemen estetika, detail, dan warna, sedangkan ciri-ciri dengan nilai tak berwujud atau tidak terlihat adalah nilai sejarah dan budaya. Contoh nilai-nilai itu bisa dilihat (tangible) di deretan gerbang-gerbang di kawasan Pecinan, seperti di Soditan terdapat gerbang rumah yang lebih didominasi oleh budaya Tionghoa melalui elemen estetika. Elemen muncul di bagian atas gerbang; terdiri dari dua kotak, di kanan dan kiri dengan gambar-gambar binatang legendaris yang dianggap suci yaitu Qilin atau Kilin, binatang setengah kuda dan naga yang melambangkan keberuntungan dan kebaikan. Bapak Hendrawan (budayawan Tionghoa) di dalam wawancara pada September 2018 di Rumah Oei, Lasem mengatakan bahwa Kilin biasanya akan muncul di dunia yang damai saja. Simbol tersebut menggambarkan harapan pemilik rumah sehingga kedamaian akan selalu mengelilingi rumah dan penghuninya. Kemudian, di Soditan ada juga unsur estetika pada gerbang, di bagian atasnya terdapat gambar rusa dan bangau. Dalam kisah masyarakat Tiongkok, kedua hewan tersebut dikenal sebagai makhluk abadi. Oleh karena itu, gambar melambangkan harapan berumur panjang dan bernasib baik bagi penghuninya (gambar 4). Di Karangturi dan Babagan, nilai tangible budaya Tionghoa ini juga banyak ditemukan di gerbang, namun dalam bentuk tulisan Hanzi yang mengekspresikan harapan baik kehidupan penghuni. Beberapa tulisan masih terlihat jelas; namun, beberapa sudah ditutup cat atau memudar seiring perjalanan waktu. Tentang "harapan-harapan" tersebut sejalan dengan yang pernah dikatakan Loukaitou dan Ehrenfeucht (2009) yang memperhatikan bahwa dalam kegiatan parade (dalam kasus ini adalah "parade" gerbang rumah Peranakan Lasem) memungkinkan orang untuk menampilkan identitas kolektif secara publik dan memberikan ekspresi kolektif untuk kegembiraan, kesedihan, harapan, klaim, atau aspirasi masyarakat.

Lokasi setiap Pecinan di Lasem dapat dicapai dengan berjalan kaki. Setelah menikmati barisan gerbang-gerbang rumah Peranakan di Soditan, penulis menuju ke kawasan Karangturi dan Babagan. Kawasan Karangturi berada dekat dengan masjid Jami Lasem yang memiliki kubah berwarna hijau. Bangunan masjid ini sering menjadi penanda bahwa "Selamat Datang, anda telah sampai di Lasem". Sedangkan kawasan Babagan dapat ditempuh dari Karangturi ke arah barat dengan menyusuri jalan Raya Pos yang dahulu di bangun pada masa kepemimpinan Gubernur Herman Willem Daendels (1808-1811). Jalan tersebut dikenal juga dengan nama dalam bahasa Belanda yaitu $D e$ Groote Postweg (P. Nas \& Pratiwo, 2002). Jalan ini memisahkan Kawasan Soditan dengan Karangturi dan Babagan.
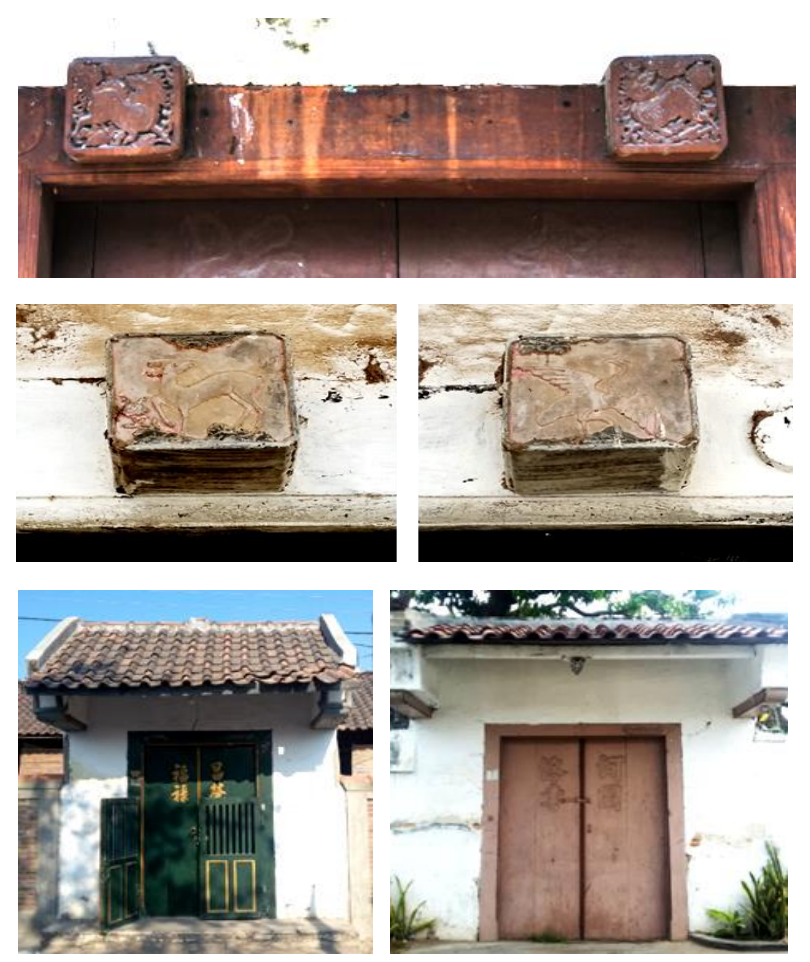

Gambar 4. Contoh Nilai Intangible: Budaya TionghoaGerbang Rumah Peranakan, Lasem. Kilin (atas), Rusa dan Bangau (tengah) \& Tulisan Hanzi (bawah)

(Sumber : Dokumentasi Penulis, 2017-2019)

Di kawasan Karangturi dan Babagan, penulis menyaksikan berbagai karakteristik gerbang yang berbeda dari kawasan sebelumnya. Di sini, identitas budaya lain yaitu Eropa mulai terlihat melalui kehadiran pilar-pilar ionik atau cerobong asap semu (Nok Acroterie) yang biasanya ditemukan di atap rumahrumah bergaya indische (Gambar 5-kiri bawah). Jika melihat kembali ke sejarah, dua wilayah ini sebenarnya berkembang pada masa kolonial Belanda, oleh karena itu, tidak dapat dipungkiri bahwa pengaruh budayanya juga mempengaruhi budaya sebelumnya. 

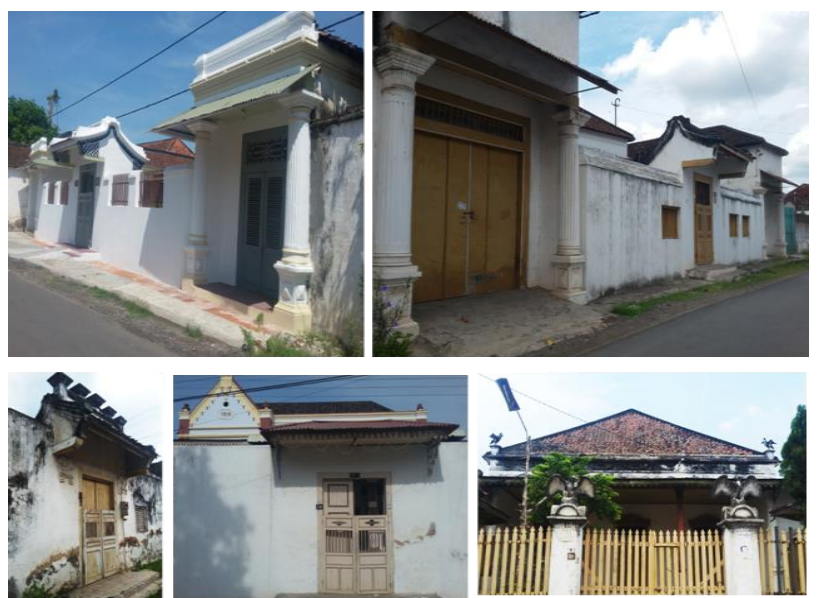

Gambar 5. Contoh Nilai Tangible: Budaya Belanda: Gerbang Rumah Peranakan, Lasem

Di kawasan Karangturi (atas) dan Babagan (bawah).

(Sumber : Dokumentasi Penulis, 2017-2019)

Mengalami tiga kawasan Pecinan berulang kali memberikan pemahaman yang lebih dalam tentang nilainilai penting yang terkandung di dalamnya. Suasana menciptakan "imajinasi puitis" yang sangat memengaruhi perasaan; rasa bangga, sedih dan marah ketika saya melihat keadaan dan kondisi gerbanggerbang tersebut. Penulis bangga dengan kekayaan sejarah dan budaya, sedih karena banyak yang dilupakan, dan marah karena karakter unik dari gerbang tampaknya ter/diabaikan. Bahkan, Pallasmaa dalam Steven Holl (1994) mengungkapkannya lebih puitis dengan berpendapat bahwa keadaan, kewujudan arsitektur lebih lengkap dari bentuk seni lainnya dan dapat mempengaruhi persepsi sensorik seseorang.

"Architecture, engages the immediacy of our sensory perception. Architecture, more fully than other art forms" Pallasmaa, 1994.

Pernyataan di atas juga dapat diekspresikan ketika melihat desain, elemen estetis dan warna dari gerbanggerbang rumah Peranakan Lasem. Sebagian besar desain gerbang di daerah Pecinan Lasem cenderung memiliki dekorasi minimum dan warna-warna yang "ramah" dengan mata, seperti biru, hijau, hijau muda, kuning, krem atau cokelat yang kemudian menjadi ciri khas gerbang rumah Peranakan Lasem (gambar 6).

Meski begitu, ada juga gerbang yang mengalami over decoration dengan tujuan untuk menarik lebih banyak perhatian (gerbang 7). Walaupun gerbangnya tidak berwarna cerah, namun warna merah terang di sekeliling tembok gerbang "mengaburkan" identitas gerbang sebagai wajah (façade-bagian luar yang dilihat pertama kali) dari rumah Peranakan yang berada di
Lasem. Ini dapat menjadi potensi untuk menurunkan nilai kelokalan, kemudian kehilangan makna. Meskipun keberadaan rumah akan mengundang perhatian, tetapi sebenarnya membuat rumah terlihat berbeda dari yang lain dan terpisah dari lingkungan sekitarnya. Keadaan tersebut mengingatkan penulis pada reaksi keras Pallasmaa yaitu berupa penolakan pada kasus Kontes Desain Museum Guggenheim di Helsinki, Finlandia. Merlin Fulcher penulis dari The Architect's Journal menulis artikel kasus tersebut pada tahun 2016 menyatakan bahwa Pallasmaa dengan tegas menolak konsumerisme arsitektur:

"wrong building for the wrong site... emphasises a consumerist and touristic view instead of strengthening local artistic tradition..."

Ia menyatakan bahwa bangunan yang salah untuk lokasi yang salah, bangunan yang hanya menekankan pada tujuan konsumerisme dan wisata saja, daripada memperkuat keindahan tradisi lokal. Perspektif yang sama, namun berbeda persepsi terhadap keadaan tersebut (tentang warna) dapat dilihat dari pernyataan Steven Holl (1994) bahwa perbedaan warna yang signifikan atau mencolok dari lingkungan sekitar sangat memungkinkan sebuah bangunan kehilangan "ritmenya", karena warna dapat mempengaruhi kondisi cahaya dan bayangannya. Mata dan rasa akan mempertanyakan tentang keadaan arsitektur tersebut. Setiawan (2020) mengatakan bahwa sebuah bangunan bisa dilihat "pergerakan" melalui perjalanan tema pada façade - nya. Namun dalam hal ini, façade dengan warna mencolok dan tambahan dekorasi justru keluar dari tema modest yang diusung bangunan rumah Peranakan Lasem. Walaupun begitu, tidak sedikit pengunjung yang mengaguminya justru karena warna merah cerah dan ornamen-ornamen tambahannya.
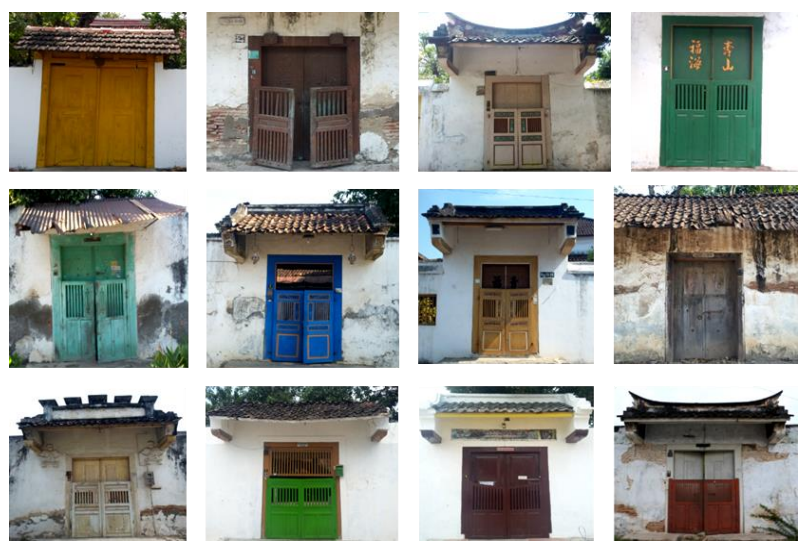

Gambar 6. Berbagai Desain Gerbang Rumah

Peranakan, Lasem di Soditan (atas), Karangturi

(tengah), dan Babagan (bawah).

(Sumber: Dokumentasi Penulis. 2017-2019) 


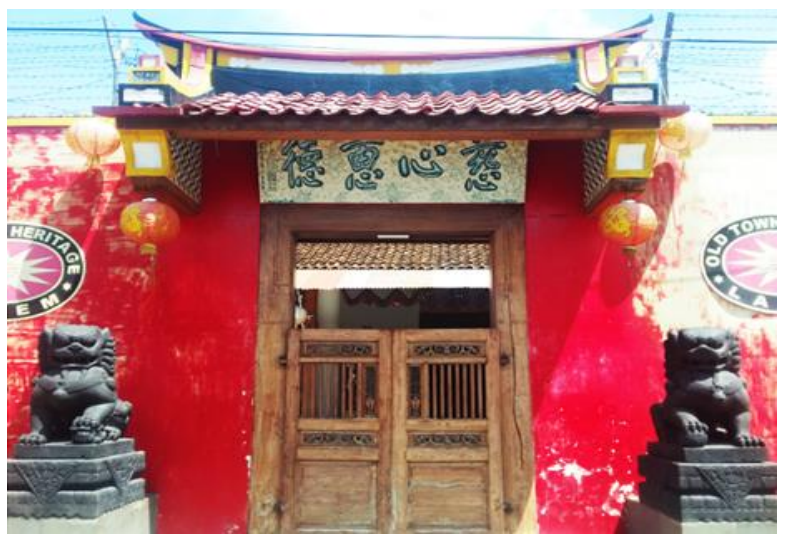

Gambar 7. Dekorasi Cenderung Ramai pada Gerbang Rumah Peranakan Lasem. (Sumber : Dokumentasi Pribadi, 2019)

Meskipun berasal dari masa lalu, gerbanggerbang ini mengambil bagian hingga hari ini. Mereka tidak hanya penuh dengan cerita sejarah dan budaya, tetapi juga sebagai bagian dari sebuah karya seni. Bahkan, secara tidak langsung, sebuah karya yang memiliki nilai tidak berwujud akan lebih mudah bertahan hidup seiring berjalannya waktu karena ia memiliki kekuatan untuk menembus periode dan bertahan dari periode klasik ke periode kontemporer. Gerbang paling sering menjadi latar belakang foto gaya kontemporer. Oleh karena itu, dapat dikatakan bahwa keberadaan gerbang berkontribusi terhadap gaya hidup saat ini, dan secara tidak langsung menjadi bagian dari upaya pelestarian budaya.

\section{KESIMPULAN}

Melalui fenomenologi, keberadaan gerbang rumah Peranakan Tionghoa di Pecinan, Lasem menjadi bermakna dan dapat diartikan atau dipersepsikan. Pendekatan fenomenologi pada artikel ini telah membawa pada pengalaman, dengan mengeksplorasi dan memahami objek penelitian. Artikel ini bukan hanya ekspresi pengalaman penulis tapi dapat juga dikembangkan lebih dalam melalui pengalaman penghuni atau pengunjung/wisatawan yang sudah merasakannya. Ekspresi dan persepsi mengenai rumah Peranakan di Pecinan, Lasem dapat mengundang orang lain untuk mengunjungi Lasem dan mengambil bagian dalam upaya pelestarian budaya. Melalui penelitian ini juga diketahui bahwa keberadaan gerbang rumah Peranakan merupakan simbol perjuangan warisan budaya di Lasem yang terus berusaha bertahan di masa modern yang kerap mengikis nilai-nilai sejarah dan budaya yang mengakibatkan terkikisnya identitas tertentu. Keberadaan pintu gerbang rumah Peranakan di Lasem juga mencerminkan keberhasilan komunikasi antara kompleksitas nilai sosial dan budaya asing -
Tionghoa dan Belanda, serta budaya lokal yaitu Jawa pada waktu itu. Dengan demikian, diharapkan keanekaragaman persepktif dan makna budaya yang melekat di pintu gerbang rumah Peranakan dapat mengundang penghuni, penduduk setempat bahkan pengunjung, untuk lebih merasa memiliki (sense of attachment) sehingga dapat lebih menghargai dan akhirnya dapat menjaga salah satu aset sejarah dan budaya bangsa Indonesia.

\section{DAFTAR PUSTAKA}

Aziz, Munawar. (2014). Lasem Kota Cina Kecil: Interaksi Tionghoa, Arab dan Jawa dalam Silang Budaya Pesisiran. Yogyakarta: Penerbit Ombak.

Basso, K.H. (1996). Wisdom sits in places: Notes on a Western Apache landscape. In Feld, S. and Basso, K.H. (Eds.), Senses of place (pp. 53-90). Santa Fe, New Mexico: School of American Research Press

Darmayanti, Tessa Eka. (2017). Third Space within the Gates of Rumah Peranakan at Chinatown Area, Lasem, Central Java, Indonesia: $5^{\text {th }}$ PSU-USM International Conference on Art and Sciences, 8-9 August 2017, Phuket, Thailand, hal. 73-82.

Darmayanti, T. E., \& Bahauddin, A. (2020). Understanding vernacularity through spatial experience in the Peranakan House Kidang Mas, Chinatown, Lasem, Indonesia. ISVS EJournal, 7(3), 1-13.

Darmayanti, T. E., \& Bahauddin, A. (2020). Pengaruh perubahan sirkulasi terhadap fungsi ruang di rumah Peranakan, Kampung Babagan, Lasem. ARTEKS: Jurnal Teknik Arsitektur, 5(2), 265-276. https://doi.org/10.30822/arteks.v5i2.403

Fromberg, Pieter Hendrik. (1911). De Chineesche Beweging op Java. Amsterdam: Elsevier.

Handinoto. (2015). Kota Tua bernuansa Cina di Jawa Tengah. Yogyakarta: Penerbit Ombak.

Holl, Steven; Pallasmaa, Juhani \& Perez-Gomez, Alberto. (1994). Questions of Perception: Phenomenology of Architecture. Architecture and Urbanism, July, Special Issue.

Kusworo, Engkus. (2009). Fenomenologi: Metodologi Penelitian Komunikasi. Bandung : Widya Padjajaran.

Loukaitou-Sideris, Anastasia \& Ehrenfeucht, Renia. (2009). Sidewalks: Conflict and Negotiation Over Public Space. Massachusetts: The MIT Press.

Merleau-Ponty, M. (2012). Phenomenology of perception. Trans. D.A. Landes. London and New York: Routledge. 
Nas, Peter \& Pratiwo. (2002). Java and De Groote Postweg, la Grande Route, the Great Mail Road, Jalan Raya Pos. In: Bijdragen tot de Taal-, Land- en Volkenkunde, On the Road the Social impact of new roads in Southeast Asia, 158, No. 4, Leiden, 707-725.

Pallasmaa, Juhani. (2005). The Eyes of the Skin. Chichester: John Wiley \& Sons Ltd.

Pratiwo. (1990). Ph.D Thesis: The Transformation Of Tradirional Chinese Architecture: A Way to Interpret Issues on Modernization and Urban Development on the North-Eastern Coast of Central Java - Indonesia. German: Aachen, Technische Hochschule.

Pratiwo. (2002). The Chinese Town Lasem. In Peter J. M Nas. The Indonesian Town Revisited. Singapore: ISEAS.

Rahmat, J. (1985). Psikologi Komunikasi. Bandung: Remaja Rosda Karya.

Rush, James R. (1990). Opium to Java: Revenue Farming and Chinese Enterprise in Colonial Indonesia 1860-1910. Ithaca, New York: Cornell University Press.

Russ, A., Peters, S.J., Krasny, M.E. and Stedman, R.C. (2015). Development of ecological place meaning in New York City. Journal of environmental education, 46(2), 73-93.

Setiawan, D., Sardjono, A., Rukayah, R., \& Harsritanto, B. I. (2020) STRUKTUR FORMAL FASADE BANGUNAN UTAMA BERSEJARAH (Kawasan Kota Lama Semarang). MODUL, 20(01), $75-$ 83. https://doi.org/10.14710/mdl.20.01.2020.75 $\underline{-83}$

Suroyo, A.M. Djuliati; Jahmin; Supriyono, Agust; Sugiyarto; Sulistiyono, Singgih Tri; Os, Indriyanto; Indrahti, Sri. (1994). Laporan Penelitian: sejarah dan Budaya Maritim Di Lasem. Semarang: Universitas Diponegoro.

Suryadinata, Leo. (1997). Political Thinking of the Indonesian Chinese, 1900-1995: A Sourcebook. Singapura: Singapore University Press

Toadvine, Ted. (2016). Maurice Merleau-Ponty. Stanford Encyclopedia of Philosophy. The Metaphysics Research Lab. Stanford Center for the Study of Language and Information (CSLI). Stanford: Stanford University.

Wijaya, Slamet. (1988) Report: EksvakasiCaruban, Lasem, Jawa Tengah. Jakarta: Dept. Pendidikan Dan Kebudayaan RI.

Website:

Fulcher, Merlin. (2016). Finnish Architect Demands Guggenheim Helsinki Rethink. Di akses pada Agustus 2019. https://www.architectsjournal.co.uk/news/finnis h-architect-demands-guggenheim-helsinkirethink/10015089.article?utm medium=website \&utm_source=archdaily.com

MacLeod, Finn. (2019). Spotlight: Steven Holl. Di akses pada Januari 2020. https://www.archdaily.com/575852/spotlightsteven-holl 